\title{
MARIAN ROBERTS, DEVELOPING THE CRAFT OF MEDIATION: REFLECTIONS ON THEORY AND PRACTICE (LONDON: JESSICA KINGSLEY PUBLISHERS, 2007)
}

\section{Ghislaine M. Lanteigne}

In Developing the Craft of Mediation, ${ }^{1}$ Marian Roberts proposes that mediation is akin to a craft with its focus on learning from experience and from others working in the field to develop and master knowledge and skills. In the mastering of a craft " $[t]$ here is an explicit assumption that the more one understands how to do something well, the more one cares about it. That requires commitment, self-discipline and self-criticism in the pursuit of quality". ${ }^{2}$ As a practicing mediator as well as a university visiting lecturer with a background in law and social work, Roberts adopts the craftsmanship approach in order to bring the reader to reflect on what it means to be a mediator through the often unheard voices of those practicing in the field. For this task, sixteen "accomplished mediation practitioner[s]"3 ${ }^{3}$ were interviewed individually and it is their insights and analysis that make the bulk of the book. What is presented is the reflective experience of masters within the professional circle of mediators. Those chosen dig into their history and experience to reveal their motivation and background, their views on the practice of mediation, and issues arising from it. Roberts complements this already rich spectrum of ideas with her own brief analysis and summaries referring also in her presentation to other authors. A rich tapestry of insights and studies about the craft of mediation informs the text.

Literature on Alternative Dispute Resolution [ADR] abounds, emanating in large part from the United States but also, for instance, from the United Kingdom and Canada. ${ }^{4}$ To a large extent, literature about ADR focuses on the process, skills, and strategies for mediation, as well as on the issues arising from it. ${ }^{5}$ Texts are written as analyses or critiques of mediation, or as prescriptive pedagogical material for newcomers or students in the field. ${ }^{6}$ Few texts have been written from the perspec-

* Ghislaine M. Lanteigne has a background in Law, Sociology, and Linguistics and is now associated with Gauthier \& Associates, Toronto

1 Marian Roberts, Developing the Craft of Mediation: Reflections on Theory and Practice (London: Jessica Kingsley Publishers, 2007).

2 Ibid. at 229

3 Ibid. at 19.

4 In terms of a compendium of excerpts of articles on ADR, see e.g. from the United States: Carrie J. Menkel-Meadow et al, Dispute Resolution: Beyond the Adversarial Model (New York: Aspen, 2004); Carrie J. Menkel-Meadow, Lela P. Love, \& Andrea K. Schneider, Mediation: Practice, Policy, and Ethics (New York: Aspen, 2006); from the United Kingdom: Simon Roberts \& Michael Palmer, Dispute Processes: ADR and the Primary Forms of Decision-Making, $2^{\text {nd }}$ ed. (Cambridge: Cambridge University Press, 2005); from Canada: Julie Macfarlane, ed., Dispute Resolution: Readings and Case Studies, $2^{\text {nd }}$ ed. (Toronto: Emond Montgomery, 2003).

5 Ibid.

6 In Canada, apart from Macfarlane, supra note 4, for works dealing with pedagogical aspects of mediation and analyses of issues related to it, see e.g. George W. Adams, Mediating Justice: Legal Dispute Negotiations (Toronto: CCH Canadian, 2003); Desmond Ellis \& Dawn Anderson, Conflict Resolution: An Introductory Text (Toronto: Emond Montgomery, 2005); Robert M. Nelson, Nelson on ADR (Scarborough: Thomson Carswell, 2003).

(2008) 26 Windsor Y.B. Access Just. 
tive of the mediators themselves in a collegial and conversational genre. ${ }^{7}$

Marian Roberts's book aims at filling this gap. The mediators interviewed have all made substantial contributions as practitioners, teachers or writers. ${ }^{8}$ They work mostly in the United Kingdom with a few working in other European countries; some from the UK have also gained experience in various countries including the United States. They represent a mixture of ages and genders and are from various backgrounds. Their original training has been in law, social sciences (social work, social psychology, psychology, criminology), and political sciences. They represent various fields of mediation: family, business, community, environment, and international. Their views are of interest to anybody practicing, studying or having an interest in mediation.

The book is divided into three parts covering eight chapters. The first part, entitled "The Mediator", introduces what motivated those interviewed to work as mediators followed by what they identify as the necessary personal qualities for the work, and finally their attitude to conflict. In the second part, "Mediation", the discussion focuses on the nature, purpose and principles as well as the theory and practice of mediation. In the third part, "The Task", experiences of practice and particular problems are explored. Finally, in the conclusion, Roberts raises the question of similarities between the processes involved in mediation and craftsmanship, as well as the contribution of mediation to society as a whole. A number of themes and sub-themes covered in this book under "Mediation" and "The Task" can also be found in the literature on mediation. ${ }^{9}$ However, what make this book stand out are living words drawn from personal involvement by a group of well-seasoned practitioners in the field.

To start with, Roberts invites the reader to get to know these mediators by having each one introduce his or her background as well as the personal qualities they find essential to their work. As subsequent themes of the book are introduced, each mediator, by then a known figure, comes to the fore and, in an informal conversation with an invisible but knowledgeable interviewer, presents his or her views on the topic being discussed. Themes and as well as reflections by the practitioners are interconnected by Roberts with the result that the reader is brought into the aliveness of the dynamics of mediation. This work has something unique as compared to the presentation of analytical, critical or prescriptive texts; it has the spark of verbatim input by mediators reflecting on the experience of their craft.

In order to introduce the main themes discussed, Roberts offers a core and introductory definition of what constitutes the mediator's task:

The mediator is distinguished as a disinterested, non-aligned third person, facilitating communication exchanges between

7 See especially Deborah M. Kolb et al, When Talk Works: Profiles of Mediators (San Francisco: Jossey-Bass, 1997) where interview-based profiles of twelve well-established North American mediators were presented in a sequent fashion.

8 Supra note 1 at $9-15$.

9 See e.g. supra notes 4 and 6. 
the parties that lead towards their own consensual joint decision-making. The mediator has neither a stake in nor any authority to impose an outcome on those parties. ${ }^{10}$

Roberts is nevertheless aware that that there are debates within the profession "as to what mediation can or should achieve" ${ }^{11}$ The practitioners interviewed do not identify themselves with a particular school of thought about the purpose of mediation but rather present a "spectrum of possible purposes from the more idealistic to the more pragmatic depending, predominantly, on the particular context of practice". ${ }^{12}$

As the practitioners present their views on the purpose of mediation, what is emphasized is how problem solving and learning both for the parties and the mediators permeate the process. For consensual settlement to happen, mediators need to favour a forum where parties exchange information and negotiate. Cooperative problem solving is at the heart of this process. From this collaborative experience, it is hoped that parties will learn to be better negotiators in the future. Some mediators identify a higher general purpose whereby people could, following mediation, learn to manage their conflicts in a more constructive way. ${ }^{13}$ The learning outcome of mediation is also seen as a unique way to deal with disputes, unavailable in litigation. ${ }^{14}$

When asked about how theory informs their practice, the mediators acknowledge drawing mostly from the social sciences. ${ }^{15}$ However, the importance of "a continuing process of clarification and self-conscious understanding of practice" 16 is underlined. The possibility of exchanges with peers and feedback from clients enables a valuable environment for learning. ${ }^{17}$ Roberts also introduces the core principles of mediation: respect for the parties, impartiality, voluntariness of participation, as well as party control and mediator authority. ${ }^{18}$ The mediators acknowledge that, in the midst of practice, these principles inform the assortment of interventions they choose. ${ }^{19}$ There are therefore constant and pressing decisions to be made by the mediator. The intensive demands on the mediator

10 Supra note 1 at 69.

11 Ibid. at 70 .

12 Ibid. Roberts refers to the debate, originating in the United States, which identifies a dichotomy of purposes for mediation: problem solving [see e.g. Roger Fisher \& William Fisher, Getting to Yes: Negotiating Agreement without Giving In (New York: Penguin, 1981)] and transformative [see Robert A. Baruch Bush \& Joseph P. Folger, The Promise of Mediation: Responding to Conflict Through Empowerment and Recognition (San Francisco: Jossey-Bass, 1994); The Promise of Mediation: The Transformative Approach to Conflict, rev. ed. (San Francisco: Jossey-Bass, 2004)]. Roberts is critical of the transformative approach at 134.

13 Supra note 1 at 79.

14 Ibid. at $87-88,91$.

$15 \mathrm{Ibid}$. at 117 .

$16 \mathrm{Ibid}$. at 112 .

17 Ibid. at 127.

18 Ibid. at $94-108$.

19 Ibid. at 94 . See e.g. Julie Macfarlane, "Mediating Ethically: The Limits of Codes of Conduct and the Potential of a Reflective Practice Model” (2002) 40 Osgoode Hall L. J. 49 at 59 where the author indicates that choices of specific interventions by the mediator during mediation reflect a given ethical framework. 
are summarised by Roberts as she writes: "[t]he mediator is expected, therefore, to maintain a calm, disinterested, rational and creative presence in the midst of the parties' stress and distress". ${ }^{20}$ Hence, the importance of debriefing, whether alone or with other colleagues, after the complex and dense unfolding of mediation. Exchanges within the guild of peers act both as a source of learning and a way of dealing with the inherent stress of the profession.

One crucial and ever constant problem of practice that is presented by Roberts and addressed by the practitioners is that of power distribution among the actors to mediation (parties and mediator). How is the arena to be shared among them? Power distribution is ever present as each party to the mediation passes from a self-focused standpoint to a collaborative endeavour with the other party or parties. ${ }^{21}$ As for the mediator, his or her maintaining an intermediate position between the parties is vital to achieving a consensual settlement. Trust among these actors (parties and mediator) will help the continuous exchange amongst them. Trust, however, has to be earned. ${ }^{22}$ In terms of the core principles mentioned above, respect by the mediator for the parties and impartiality on his or her part towards them will help in the establishment of trust. Ways of expressing respect for the parties include a non-judgemental stance, empathy, even-handedness, and patience. ${ }^{23}$ As for impartiality, Roberts distinguishes it from neutrality by indicating that "mediators are not necessarily neutral, inevitably having their own values, views, feelings, prejudices and interests". ${ }^{24}$ This is echoed by mediators interviewed. However, impartial treatment of parties by the mediator is a necessary principle of mediation as its realisation can ensure a fair process. The comments by mediators on this topic reveal their considering this as an attribute and skill but also a duty. ${ }^{25}$ Elements mentioned to enable impartiality to be achieved are a balanced respect for parties, not siding with one side and the realisation that there is not one truth but different perceptions of reality. ${ }^{26}$

The particularity and autonomy of the profession is also addressed. ${ }^{27}$ In this respect, the practitioners interviewed recognize that, although they draw from their other professional background, whether in law, social sciences or political science, being a mediator requires putting on a new hat. While communication or negotiation skills may have also been necessary in their previous or other profession, the particular dynamics of mediation are recognized. The requirement to be in one professional role at a time is underlined.

This book covers a wide range of themes and sub-themes that arise in the discussion on the theory and practice of mediation. These are clearly organised

20 Supra note 1 at 183.

21 See e.g. Genevieve A. Chornenki, "Exchanging 'Power Over' for 'Power With", in Julie Macfarlane, ed., Rethinking Disputes (Toronto: Emond Montgomery, 1997) at 164 - 165. Ellis \& Anderson, supra note 6, in c. 4, report on a number of theories and studies on the distribution of power between parties to mediation.

22 Supra note 1 at 175.

23 Ibid. at $96-97$.

24 Ibid. at 98.

25 Ibid. at $97-101$.

$26 \mathrm{Ibid}$. at $97-100$

27 Ibid. at 80-86. 
and presented in the first and second parts of the book. However in the third part, entitled "The Task", the organization of sub-themes is harder to decipher. It becomes all the more striking in this part, which has a rather long list of subthemes, that a clearer organisation and presentation of these in all parts of the book (use of numbers, for example, to identify sub-themes) would have made the text somewhat more user friendly.

Roberts's book is nonetheless comprehensive and an excellent contribution in demystifying the role of the mediator acting behind the veil of confidentiality that surrounds mediation. Respectful of this aspect, the chosen mediators enable the reader to reflect on the dynamics and complex demands of this role. In the larger context of legal pluralism, this book contributes to defining not only the role of the mediator as an agent of change in dispute resolution between parties but also as an agent of change in the expanding sphere of dispute resolution mechanisms. This book also adds to defining the profession at a point of time when it is still seeking to anchor its place in modern society.

Roberts, truthful to her background, has chosen a genre that enables the reader to also become active in the quest for means of solving disputes between people. What I like about this book is its drawing the reader into the reflective process already engaged in by the mediators. It is also possible to put this work down and come back to it feeling that, as a reader, you are re-witnessing well organised informal talks by masters you are coming to know better and are curious about. The environment is well set for learning.

Developing the Craft of Mediation is an invitation to meet mediators who, through experience and reflection have matured in "this ancient and universal craft", ${ }^{28}$ and can articulate what is "effective practice". ${ }^{29}$ Marian Roberts has aptly channelled their presentations by providing the topics and the venue. The reading is worth the commitment.

28 Ibid. at 228.

29 Ibid. at 208. 